\title{
THE CLASSICAL ASSOCIATION OF SOUTH AFRICA: FEBRUARY 1979 - JANUARY 1981
}

\author{
W J Henderson (University of Johannesburg)
}

This instalment rounds off the history of the Classical Association of South Africa for the first twenty-five years. ${ }^{1}$

1. Thirteenth CASA conference, 30 January - 2 February 1979, Rand Afrikaans University, Johannesburg

\subsection{Conference proceedings}

At the First Business Meeting on 30 January, the Chairperson, Prof Dietrich, welcomed the 42 delegates. ${ }^{2}$ Among the matters arising was the resolution that the periodicals received in exchange for Acta Classica were to become the possession of the University of South Africa, with the understanding that CASA members would have access to them and receive free photocopies of articles. Concerning the prerequisite for law study, ${ }^{3}$ Prof Kriel reported that he had consulted with the Secretary and Chairperson of the Bar Council and with the Association of Law Societies. It was decided to leave the matter in the hands of the law societies for the time being.

The Treasurer's report was then tabled by Dr Basson. There was a credit balance of R586 in the savings account. The sum of R1 000 invested in paid-up shares in April 1967 had grown to R2 174. An amount of R2 000 had been paid toward the printing costs of Acta Classica, which included an accidental overpayment of R250 in 1978, while R450 had been paid to Akroterion. The Treasurer's recommendations that the excess payment of R250 be paid to

1 For the earlier articles, see Henderson 2004, 2005, 2006, 2007, 2008. For the namechanges of provinces, cities and universities, see Henderson 2004:89 n. 3 (Rhodesia, Orange Free State, Rand Afrikaans University); 2005:109 n. 1 (University of Natal, South West Africa); 2006:135 n. 6 (University for Christian Higher Education, Potchefstroom), 138 n. 26 (University of Zululand); 2007:109 n. 59 (Port Elizabeth).

2 A notable absentee was Prof Petrie, who sent his apologies and good wishes. Ill health later forced him to leave the Victoria Club in Pietermaritzburg and reside with his daughter in Johannesburg. Naudé to C, 10 May 1979. The Executive sent him a card congratulating him on his 98th birthday (Minutes of Executive, 19 November1979). At a reception in his honour at the Old Wanderers Club he delivered a witty extempore oration on "Old Age"; see Petrie 1980.

3 Minutes of Second Business Meeting, 1977. 
Acta Classica and that the interest accrued on the fixed investment be deposited in the savings account were approved. The membership of the Association had increased to 163 full members, 44 associate members, 38 student members and 12 honorary and life members. Subscriptions totaling R122.85 had been paid to FIEC for the three years 1976-1978.

Prof Naudé, treasurer of Acta Classica, reported that the number of exchange periodicals now stood at 78 , and that this was an important component in the editorial committee's application to the Human Sciences Research Council for an annual grant (now R1 500). Prof Naudé explained that the publishers, A A Balkema, tried their best to keep costs down, receiving 33,3\% of all sales plus $20 \%$ of all copies handled (sales and distribution). For example, the calculations for vol. XX were as follows: sales $192 \times$ price per volume R7,50=R1 440, 33,3\% $=\mathrm{R} 480$, plus number of copies handled $470 \times \mathrm{R} 1,50=\mathrm{R} 705$, giving a profit of R1 185. This left an accumulated credit of R482 on the journal's account. Vol. XX (1977) had cost R4 300 and the balance of R3 818 had been paid. The cost per page averaged R18,50. Contributions from universities had been encouraging: R400 in 1977, R829 in 1978. It was recommended that letters of thanks be sent to the publishers and to the universities which had made financial contributions to the journal; that the grant from CASA be increased to R1 000; that the incumbent editorial committee be re-appointed for the period 1979-1980, with the addition of Prof Vogel as Assistant Editor; and that the following collaborators be added to the list: Proff Drijepondt (University of the Orange Free State), Botha (University of Port Elizabeth), Benade (University of the North), Van der Walt (University of Zululand), Els (University of Fort Hare), Snijman (University of the Western Cape), Cipolla (University of DurbanWestville) $^{4}$ and Saddington (University of Rhodesia). The recommendations were accepted.

The report on Akroterion was read out on behalf of the Editor, Prof Smuts, who was abroad. Appreciation was expressed to the collaborators, CASA and the University of Stellenbosch. Concern was also voiced about rising costs.

The FIEC representative, Prof Arnheim, explained the problems he had encountered, in particular the fact that this body did not provide information on international conferences. Prof Louw's proposal that the incoming Executive Committee should reconsider the advisability of continued membership and also investigate the possibility of affiliation with other bodies, was accepted.

In her report as convener of the subcommittee for Latin in Schools, ${ }^{5}$ Dr Bruwer gave a detailed account of the progress made. She was thanked for her

\footnotetext{
4 Now incorporated in the University of KwaZulu-Natal.

5 Minutes of Second Business Meeting, 1977.
} 
hard work. The subcommittee was re-appointed, with the exception of Proff Dietrich and Henderson and the addition of Dr Atkinson. Prof Arnheim reported progress in the work of the Subcommittee for Classical Civilisation Courses and was requested to continue as convener.

Prof Henderson tabled a report on the activities of the Subcomittee for Publications. The subcommittee had a widely representative membership: Proff Dietrich (Rhodes), M M Henderson (Natal), Kriel (Pretoria) and Smuts (Stellenbosch), with liaison members Proff Arnheim (Witwatersrand), Benade (Orange Free State), Botha (Port Elizabeth), Cipolla (Durban-Westville), Coetzee (Potchefstroom), ${ }^{6}$ Els (Fort Hare), Lubbe (Unisa), Snijman (Western Cape), Van der Walt (Zululand), Dr Atkinson (Cape Town) and Mr Scholtemeijer (North). ${ }^{7}$ A circular was sent to all Departments of Classics, Latin and Greek in South Africa, and to publishers. ${ }^{8}$ The publishers who replied required further information on the kind of books, numbers of students and general readership. ${ }^{9}$ The following recommendations, based on the responses of departments and publishers, were submitted for consideration:

1. A survey needed to be undertaken of all students in the undergraduate courses in Greek, Latin and Classical Civilisation.

2. A similar survey should be undertaken of all pupils studying Latin at school in all the provinces.

3. To facilitate the above, members of the Subcommittee for Publications should serve on the Committees of the Regional Branches.

4. Departments should exchange material in cheaper format with a view to evaluation and co-authorship.

5. Intra- and inter-departmental projects would speed up production and increase circulation.

6. A variety of study material would provide more interest and a wider choice for the Education Departments to prescribe.

6 Prof Coetzee passed away in 1980; notice in Akroterion 25.4 (1980) 32; tribute in Akroterion 27.1 (1982) 35.

7 Prof Dietrich left South Africa and was replaced by Prof D B Gain; Prof Benade moved to and represented the University of the North and was replaced by Prof Snyman.

8 Afrikaanse Pers Beperk, Academic and Lex Patria, Butterworths, Cambridge University Press, De Jongh, HAUM, Human \& Rousseau, Juta's, Longman's, Macmillan, Maskew Miller, Nasionale Pers, Nasou, Oxford University Press, Tafelberg Uitgewers, Van Schaik, Voortrekkerpers.

9 Butterworths, HAUM, Maskew Miller, Nasou, OUP, Perskor, Van Schaik. 
7. Though the special needs and circumstances in South Africa were to be taken into account, quality work was required in the interests of education and Classical studies.

A list of recently published works was appended: B X de Wet, Learning Greek through the New Testament (Durban 1976); D B Gain, The Aratus ascribed to Germanicus Caesar (London 1976); D M Kriel, Latyn vir Regstudente (Pretoria 1977); G v W Kruger, Inleiding tot die Studie van Nuwe Testamentiese Grieks (Stellenbosch 1976); Rondom die Antieke Boek (Stellenbosch 1977); J P Louw, Semantiek van die Nuwe Testamentiese Grieks (Pretoria 1976). ${ }^{10}$

The invitation extended by the University of Natal (Durban) in 1977 as the venue for the next conference was accepted. Rhodes University was chosen as an alternative and Pretoria University for $1983 .{ }^{11}$ The theme of the conference was to be "Democracy and Imperialism in the Graeco-Roman World".

That evening Prof Viljoen, Honorary President of the Association and Rector of the Rand Afrikaans University, delivered an address on the value of the study of Classics. ${ }^{12}$ This was followed by a reception.

The Second Business Meeting was held on 1 February 1979, and attended by 39 delegates. The following regional representatives were appointed to the subcommittee for publications: Drs P Murgatroyd and Atkinson, Mr Cilliers and Prof J M Grové. The following proposals were accepted:

1. that papers received after the closing date would be considered last for inclusion in the programme;

2. that there should be a rotation of speakers;

3. that preference be given (ceteris paribus) to speakers from centres other than the venue;

4. that a short summary of the paper be submitted with the paper for inclusion in the programme;

10 For other works, see Henderson 2008:90, 92-93.

11 Minutes of First Business Meeting, 30 January 1979.

12 An edited version was subsequently published; S to C, 10 April 1979; Viljoen to S, 28 February 1979; see Viljoen 1980. This would prove to be one of the last direct contributions by Prof Viljoen in the context of the Association's activities. He was appointed Administrator General of South West Africa from 1 August 1979 and afterwards he embarked on a political career, becoming first Minister of National Education before holding various other portfolios. He was a leading figure in the formation of CASA in 1956 and the launching of Acta Classica in 1958. He passed away on 29 March 2009. See Kriel 2009; Martin 2009. 
5. that the Executive have full authority to finalise the programme, taking suggestions of the previous conference into account;

6. that membership fees be raised to R10 (Full), R4 (Associate) and R2 (Student);

7. that the amount of a registered member's subscription to be paid to the Regional Branch be raised from 50c to R1.

The meeting also suggested to the new Executive that there should be only two sessions per day (sessions meaning morning, afternoon, evening); that papers be restricted to 35 minutes, with 25 minutes for discussion; that one day should be set aside for shorter papers not dealing with the main theme; that the Executive Committee should meet on the day before the conference to make more time for the papers and first business meeting.

During a closed session, Prof Naudé was unanimously elected as an Honorary President of the Association and the following office bearers were elected: Prof Henderson (C), Prof Kriel (VC), Dr Bruwer (S), Mr Mans (T) and Prof De Wet (AM).

Motions of thanks were expressed to the Rector and Public Relations Office of the Rand Afrikaans University, the Department of Classics and the outgoing Executive.

Several matters were raised under General. Prof Saddington was appointed representative for the University of Rhodesia on the editorial board of Acta Classica. Prof Kriel announced that the University of Pretoria was to hold a Roman-Italian Festa Romana on 13-22 September 1979, during which an Afrikaans production of the Menaechmi would be performed. Prof Kriel also announced plans for a hiking-trip from Florence to Rome from 29 November to 23 December for CASA members. Prof Naudé raised the possibility of inviting foreign scholars to visit South Africa, and was requested to investigate the matter, with Dr Atkinson and Mr Cilliers to assist him. Prof Van Rooy requested the Executive to consider organising an excursion during the next conference. Prof Hendrickx raised the possibility of affiliating the Mediaeval Association of Southern Africa with CASA. The matter was referred to the next conference. A request came from Prof Gonin for articles to be submitted to Acta Classica before 15 March and Afrikaans articles to be provided with an English abstract. Finally, the meeting decided that the Executive should consult with Prof B Bierman of Natal and Prof Gus Hermansen of Alberta regarding the possibility of inclusion in the Canadian School of Hellenic and Roman Studies in Rome. $^{13}$

13 Minutes of Second Business Meeting, 1 February 1979. 
During the conference 16 papers were read. Visits were also organised to the collection of museum copies of Greek sculpture housed in the Department of Classics.

\subsection{Administration 1979-1981}

\subsubsection{General}

A letter of thanks and appreciation was sent to Prof Viljoen as Rector of the host university and guest speaker. ${ }^{14}$ The new Treasurer made the necessary arrangements for the transfer of the savings account to the Hatfield, Pretoria, branch of SA Permanent Building Society. ${ }^{15}$ New legislation required a transmission account, which paid interest of 2,5\% rather than the previous $5 \%$, but provided a cheque-facility. ${ }^{16} \mathrm{~A}$ new membership application form was designed for distribution to the Regional Branches; the idea was to allow local branches to give regular updates on their activities in addition to using it to increase membership, in particular among students. ${ }^{17}$

Correspondence was taken up with Prof Hermansen regarding his suggestion of South Africa's association with the Canadian School of Hellenic and Roman Studies in Rome. He explained that the School had become the University of Alberta Summer School and that a new Canadian Academic Centre in Italy had been created with government funding. The Centre, opened in February 1979, with Prof Alastair Small as Director, was intended to assist Canadian scholars with practical problems such as accommodation and introductions to Italian institutions, and to provide facilities (xerox machines, typewriters, slide projectors, a library). It also directed excavations and conducted seminars. The exclusion of South Africa from the Commonwealth could constitute an obstacle to an official liaison between the Centre and South African universities. However, informal contact would be welcomed. Groundwork was anticipated during the planned peregrinatio of Prof Kriel and some colleagues (Dr Bruwer, Mr J C Zietsmann) to Italy; consultations with Italian scholars would be arranged to publicise South Africa's presence and discussions held with the Director and staff of the Centre. Prof Biermann should also be involved in negotiations and Prof Hermansen could visit South Africa and perhaps attend a

14 C to Viljoen, 7 February 1979.

15 T to C, 13 February 1979.

16 Basson to T, 18 February 1979; 10 April 1979.

17 S to De Wet, 10 April 1979; C to S, 14 May 1979; Circular to all Regional Branches and Departments of Classics. 
CASA conference. ${ }^{18}$ Regarding the proposed visit of Prof Hermansen, the Executive decided to contact Prof Naudé to arrange an invitation from the Department of National Education. ${ }^{19}$

At a meeting of the Executive on 19 November 1979 at the home of Prof Kriel in Pretoria it was decided that Prof Kriel and Dr Bruwer were to contact Proff Small and Hermansen regarding liaison with the Canadian Academic Centre, while the Chairperson was to consult with Prof Biermann..$^{20}$ In the meantime the comment, advice and possible financial support of all Departments of Greek, Latin, Classics, Art, History of Art and Architecture in South Africa was to be sought. Since it was unlikely that either the South African or Canadian government would contribute financially before something concrete and viable was established, it was advisable that contact should be made on an informal and personal level. ${ }^{21}$

\subsubsection{The position of Latin}

Early in 1979 it was learned unofficially that the Department of Justice intended to request universities to introduce "Latinless" LL.B. courses for prospective magistrates. The majority of members of the Law Faculties at Afrikaans-medium universities were opposed to this idea, since its implementation would seriously damage a part of South Africa's Roman-Dutch legal heritage. Canvassing among members of Law Faculties was suggested. ${ }^{22}$ Although strong opposition to the proposal and affirmation of the value of Latin for Law was also registered at the Rand Afrikaans University, it was felt that little could be done to counteract the anti-Latin lobby in the Transvaal and the government: the political agenda would out-weigh any cultural or educational values. ${ }^{23}$ But concerted

18 S to C, 7 September 1979; Hermansen to S, 23 August 1979.

19 Minutes of Executive Meeting, 2 January 1980.

20 Minutes of Executive Meeting, 2 January 1980.

21 C to S, 13 October 1979.

22 Drijepondt to S, 28 March 1979; to C, 4 April 1979.

23 C to S, 14 May 1979. On 26 April 1978, Chief Justice F Rumpff, Patron of CASA since 1975, delivered the first L C Steyn Memorial Lecture at the university ("'n Waardering van die bydrae tot die ontwikkeling van die regswetenskap in die appèlhofuitsprake van Hoofregter L.C. Steyn"); therein he argued that the study and knowledge of Latin were indispensable for the study of law. C to S, 13 October 1979. Cf. also the opening speech of Appeal Court Judge J Trengove at a conference of Law Teachers at the University of Port Elizabeth in 1980, an extract of which appeared in Akroterion; see Trengove 1980. See also Scott 1980. At a meeting with headmasters of Western Cape schools at the University of Cape Town on 8 October 1980 it was 
resistance was nevertheless needed. ${ }^{24}$ For the present a questionnaire was designed to be sent to all Latin departments in order to assess the factual situation. ${ }^{25}$

The crux of the matter was the interpretation of Art. 3(2) of the Act regarding admission of Advocates, no. 74 of 1964, which stated that "at least one course in the Afrikaans language, at least one course in the English language and at least one course in the Latin language which is prescribed or recognised by a university for a baccalaureus degree." This formulation had long been interpreted as requiring prospective advocates to pass a university course in post-matriculation Latin, that is Latin I. To provide for students who had not had the opportunity to study Latin at school, one- or two-year courses in Preliminary or Special Latin, which did not count as credits for a baccalaureus degree, were introduced at universities. In 1977 the Act was revised so that the two official languages (English and Afrikaans) and Latin no longer needed to be an integral part of the LL.B. course itself, although the three languages were still required for admission to the legal profession. The main motivation for the change was that under the Act of 1964 students from Rhodesia were forced to do Afrikaans. It was then only a matter of time before a Latinless LL.B. was introduced. When the numbers of students taking Latin at school and university began to decline and pressure mounted in Arts and Law Faculties, the spirit and intention of the Act could be bypassed by turning the preliminary or special courses into one-year degree credits.

A provisional memorandum was drawn up and circulated among Executive members with a view to submission to the Committee of University Principals (CUP) ${ }^{26}$ In his comment on the memorandum, Prof Drijepondt reported that he had had the opportunity to hold discussions with judges of both the Supreme Court and the Appeal Court in Bloemfontein, as well as with the Minister and Deputy Minister of Justice. There was general but guarded consensus in favour of Latin. Research was being conducted by two members of the Law Faculty on the extent to which South African Common Law was indebted to Roman and Roman-Dutch Law. This would be sent to the Minister. Judge Dr (later Chief Justice) P J Rabie was preparing material from his own and others' publications to incorporate in the research. He would also hold talks with the Minister and Secretary. Also, the new Head of Training in the Department of Justice, Dr N J van der Merwe, was more sympathetic to Latin than his predecessor. There was therefore a distinct possibility that the issue would be resolved internally

explained that a post-matriculation course in Latin "was still in force and was unlikely to be dropped"; Report in Akroterion 26.4 (1981) 39.

$24 \quad$ S to C, 4 June 1979.

25 S to De Wet, 10 April 1979; C to S, 14 May 1979.

26 S to C, 7 September 1979; S to C, 14 September 1979. 
in the Department of Justice. However, CASA had to state its position forcefully before a bill was presented to Parliament. It was suggested that the Chairperson and Secretary arrange an interview with the Minister. ${ }^{27}$

After consultation with Proff De Kock and Kriel, the Chairperson sent a circular to members of the Executive Committee in which principles and procedure for any action by CASA were set out. The proper channel in such a case was the CUP, but the documentation was as yet incomplete and unscientific. The Executive could not intervene on behalf of the Association in the promotion policy and procedure of the Department of Justice; a confrontation with the Minister was therefore out of the question, at least without approval from CASA. The approach should rather be on a personal level; the declared support of the Minister, Deputy Minister and Justice Rabie was of far greater value than using CASA as a pressuregroup. If and when the matter became official (for example, in the form of an announcement or a bill), the Association could make an official representation via the CUP, with supporting documentation (statistics, views of lawyers, academics, politicians) and a memorandum. It was essential to build goodwill and support behind the scenes and demonstrate the cultural worth of our disciplines in our educational circles and society at large.

The matter was discussed at the meeting of the Executive Committee on 19 November 1979. The provisional report on Latinless LL.B. (together with the comments of members of the Executive) and the completed questionnaires received from 16 universities (of 17 sent) were discussed. The Secretary would send a letter to Mr J P J Coetzer, the Secretary of Justice, in connection with certain remarks made in favour of a Latinless LL.B. during a speech at a graduation ceremony at Unisa on 2 May 1979. A memorandum based on the provisional report would also be sent to the CUP with the request that consideration be given to the possible standardisation of the Latin requirement for LL.B. at all South African universities. ${ }^{28}$

A letter was written to the Committee of University Principles, referring to the comments of Mr Coetzer and reporting the results of the survey conducted among the law faculties of South African universities. The survey found that

1. the majority (10) of the law faculties (Potchefstroom, Pretoria, Western Cape, North, RAU, Cape Town, Unisa, Port Elizabeth, Orange Free State, Stellenbosch) were opposed to a Latinless LL.B.;

2. four law faculties (Zululand, Fort Hare, Durban-Westville, Natal-Pietermaritzburg) were undecided;

27 Drijepondt to S, 12 September 1979.

28 S to C, 5 November 1979; Minutes of Executive Meeting, 2 January 1980. 
3. two law faculties (Rhodes, Natal-Durban) were in favour of abolishing Latin;

4. the University of Zululand already offered an LL.B. without Latin as a qualification for employment in the Department of Justice;

5. at the University of Natal-Durban there was the anomaly that students without Matriculation Latin could obtain an LL.B. with only one year of university Latin, while students at the University of DurbanWestville without Matriculation Latin had to complete three years of Latin (Preliminary Latin for two years followed by Latin I);

6. the opposition to Latin appeared at universities (Rhodes, NatalDurban) where only one year of university Latin was required of students without Matriculation Latin;

7. the requirement at Rhodes of "Latin I if a candidate has a matriculation pass in Latin, Latin Preliminary if not" discriminated against the student with Matriculation Latin;

The following recommendations were made:

1. that attention be given to the standardisation of the Latin-component of the LL.B. course;

2. that a single university course for students without Matriculation Latin could not be regarded as academically meaningful;

3. that it was considered desirable that Latin I (preceded by either Matriculation or Preliminary Latin) should be a prerequisite for LL.B.;

4. that the anomaly evident in the requirements of the Universities of Zululand, of the North and of Durban-Westville should receive attention;

5. that the CUP resist any attempts of the Department of Justice to prescribe to the universities by instituting an LL.B. degree without Latin. $^{29}$

The Secretary of Justice sent a copy of an internal, official circular to Prof Lubbe. ${ }^{30}$ In it he explained that the proposed postgraduate Latinless qualification was aimed at the lower courts and other professions where Latin was not needed. The perception that in his speech at Unisa he was advocating the abolition of Latin

S to CUP, 2 January 1980.

30 Coetzer to Lubbe, 15 January 1979; Circular no. 45 of 1979, 14 December 1979. 
from law studies was therefore incorrect. His intention was to address the practical demands within the system of justice and keep up with changes and developments by creating more types of LL.B. Latin was to remain a requirement for advocates, and officials were still encouraged to do the LL.B with Latin. He cited as an example Unisa's course in Latin Special for Law (introduced in 1974 and revised in 1979) and Latin I for Law (introduced in 1975), based on legal texts and including a component on Roman constitutional history. He was therefore not against Latin, which was an undeniably stimulating and valuable subject; LL.B. with Latin was still the priority, and LL.B. without Latin as another possibility.

Additional support for the retention of Latin came from Justice G G Hoexter, Head of the Commission of Inquiry into the Structure and Functioning of the Courts ${ }^{31}$ and the Executive decided to await further developments. ${ }^{32}$ This came in the form of an invitation to members of the Executive to lunch with the Secretary of Justice, in response to Dr Bruwer's letter of 16 January 1980.33 Prof Kriel and Drs Bruwer and Mans, along with two senior officials of the Department of Justice, attended the informal discussion over lunch on 28 May 1980. A letter was sent to the Head of Training in the Justice Department, in which the problem of the shortage of trained officials in the Department was acknowledged, but the Association's position regarding Latin for law studies was strongly restated. Such a single course at university left a wrong impression of Latin as simply grammar to be learnt by rote and did not equip students adequately to read Latin. This would lead to the eventual abolition of Latin for law studies. ${ }^{34}$ This proved to be prophetic: in 1981 Latin became an optional subject for all LL.B. degrees at Unisa - although Latin was still a requirement for an advocate. ${ }^{35}$ The Law Faculty at RAU also expected pressure if student numbers declined; the CUP was scheduled to meet in Grahamstown on 30 July 1980 and discussions could still be held with university principals before the meeting; and the outcome of the meeting and future policy and actions of the Association would have to be discussed at the forthcoming conference. For the time being the Executive had done all it could without harming the Association. ${ }^{36}$

31 Drijepondt to S, 4 February 1980; S to C, 9 February 1980; S to Drijepondt, 9 February 1980. Interim reports appeared from 1980-83, and the final report was published in Pretoria in 1983.

32 Minutes of Executive Meeting held at Pretoria University on 16 April 1980, chaired by Prof Kriel in the absence of Prof Henderson.

33 Minutes of Executive Meeting, 16 April 1980.

$34 \quad$ S to Van der Merwe, 29 May 1980.

35 Drijepondt to S, 27 May 1980.

36 C to S, 27 June 1980; S to C, 23 July 1980. 
The position of Latin at schools was worsening, especially in the Transvaal. Immediate and aggressive action country-wide was required. The delay in launching the promised report of the HSRC on the position of Latin was causing concern, and Prof Viljoen promised to lend his support. ${ }^{37}$ In July the launch of the project was announced. Dr Bruwer and Prof Kriel were to represent the Association on the ad hoc advisory committee. ${ }^{38}$ At an Executive meeting on 19 November 1979, Dr Bruwer reported that the HSRC group conducting the investigation into the position of Latin at school had visited Stellenbosch for two days in October 1979 for discussions with Prof Smuts and Dr Bruwer; Dr Bruwer would in turn meet with the group in Pretoria on 20 November 1979. ${ }^{39}$

A request by the French Committee of the Conference of Heads of Private Schools to the Joint Matriculation Board to examine French, Latin and German on the Standard Grade as well as the Higher Grade in the Transvaal was supported by the Faculty of Arts at the Rand Afrikaans University. ${ }^{40}$ Colleagues at Stellenbosch strongly opposed the idea on the grounds that it would place an extra burden on teachers and examiners and fail to produce the required results; the present basic syllabus, and in particular the Culture component, were rather to be scrutinised. ${ }^{41}$

\subsubsection{Acta Classica}

The number of periodicals received in exchange for Acta Classica in the period 1980-81 stood at $68 .^{42}$ Prof Lubbe proposed to the Executive Committee that Vol. XXIV (1981) be dedicated to Prof Gonin. The proposal was sent to Prof Vogel, Managing Editor of Acta Classica, with the comment that the Executive Committee and Editorial Board should draw up guidelines for the procedure. ${ }^{43}$ There was as yet no provision in the Constitution for such a dedication; previous cases had been based on ad hoc decisions. The matter would be brought up at the forthcoming conference: the Executive Committee would formulate criteria and procedures at its meeting before the conference and table a proposal at the First Business Meeting. ${ }^{44}$

S to C, 10 April 1979; Viljoen to S, 28 February 1979.

38 S to C, 20 July 1979. Other members of the committee were Proff Dietrich and M Henderson and Dr Griessel; see Henderson 2008:90.

39 Minutes of Executive Meeting, 2 January 1980.

40 C to S, 14 May 1979.

$41 \quad$ S to C, 4 June 1979.

42 Cf. Hasse 1981.

43 Lubbe to S, 11 August 1980; S to Vogel, 19 September 1980.

44 Vogel to S, 13 October 1980; C to S, 17 October 1980; S to C, 22 October 1980. 


\subsubsection{School and university texts}

Further correspondence was conducted with publishers. Butterworths wanted a meeting and information on the progress of the proposed texts for Cape schools undertaken by a team of Stellenbosch and Cape Town University lecturers and Cape school teachers ${ }^{45}$ a survey in Afrikaans of Latin literature by Proff Kriel and Henderson, and Afrikaans translations of Greek lyric by Proff Barkhuizen and Henderson, all of which were in a germinal phase. ${ }^{46}$ Human and Rousseau Academica recognised the need for suitable text books, invited manuscripts and requested statistics of student numbers. ${ }^{47}$ This publisher was considering the publication of a book on Roman private life (with photographs and sketches) by Dr Basson, a project which was recommended for use in schools. ${ }^{48}$

Persistence paid off in two cases. Dr Murgatroyd had failed to get his revised $\mathrm{PhD}$ thesis, a commentary on Tibullus I, accepted by Brill without a hefty subsidy, and the University of Natal Press regarded it as "too sophisticated" since it contained Greek. ${ }^{49}$ Correspondence was exchanged with Macmillan South Africa, who had recently proclaimed that the parent company in London had invested R6 million in their South African operation specifically to promote, inter alia, academic works. ${ }^{50}$ However, although recognising the merit of the work, they first wished to consult with the London company since they were concerned about the restricted market. ${ }^{51}$ In the end they decided that the book "would not be a suitable one for their list." ${ }_{52}$ Meanwhile negotiations continued with $\mathrm{H}+\mathrm{R}$ Academica. They also cited the limited market for such a book and recommended OUP and Longman-Penguin in Cape Town. ${ }^{53}$ The same scenario was played out with Butterworths: the book was too advanced for undergraduate students, the potential market too small. ${ }^{54}$ The fact of the matter was that it was highly unlikely that a commentary on a Classical author would sell more than 100 copies in

45 See Atkinson 1978 and Appendix B.

46 Mr K. Prinsloo to C, 2 and 7 February 1979; C to Prinsloo, 13 February 1979.

${ }_{47}$ Ms N du Plessis to C, 7 March 1979; 29 May 1979.

48 Du Plessis to C, 29 May 1979; C to Du Plessis, 6 August 1979. This work eventually appeared as In en om die Romeinse Huis (University of the Western Cape, Belville 1982).

49 Murgatroyd to C, 4 June 1979.

50 C to Murgatroyd, 7 June 1979.

51 Ms C Kentridge to Murgatroyd, 21 June 1979.

52 Kentridge to Murgatroyd, 4 September 1979.

53 Du Plessis to Murgatroyd, 26 June 1979.

54 Prinsloo to Murgatroyd, 13 September 1979. To add to the disappointment, an application for a grant from the Human Sciences Research Council was unsuccessful; Murgatroyd to C, 2 July 1979. 
South Africa, whereas for a publisher to break even, 2000 copies would have to be sold over four years. Publishers would have to be convinced of the intrinsic and long-term value of such a book. The relationship between Classical studies and the publishing industry was only beginning; if successful, Murgatroyd's work would be the first of its kind. The universities themselves, it was felt, also had an obligation in this regard and should be persuaded to make a contribution, which was undeniably in their own interests. ${ }^{55}$ In the ensuing years this would, in fact, become regular practice. ${ }^{56}$ Eventually, after a grant of R2 500 from the HSRC and a similar amount from the university, and a strong speech by Prof M M Henderson in the senate of the university, the University of Natal Press agreed to publish the work. ${ }^{57}$

More immediately successful was Prof Van Rooy's Antieke Griekse Geskiedenis. The work had been on the list of projects sent to various publishers and Butterworths now offered to publish it. This was duly recommended. ${ }^{58}$

\subsubsection{Visitors}

Dr Atkinson suggested inviting Prof Frank Goodyear, who would be visiting Salisbury in November as External Examiner at the University of Rhodesia, and who had indicated that he would like to visit other universities and give lectures, if this was viable so late in the year. Seminars and lectures arranged by the Western Cape Branch and at RAU were suggested. ${ }^{59}$ In June 1979 Dr Halperin from Israel conducted a seminar on Aristotle's Poetics at the University of Cape Town. ${ }^{60}$

\subsubsection{Next conference}

A circular was sent to all members on 17 January 1980, inviting papers and setting out the relevant information and the guidelines decided on at the last conference

55 C to Murgatroyd, 22 August 1979.

56 See Appendix A.

57 Murgatroyd to C, 7 December 1979. See Appendix A. Murgatroyd's commentary on Ovid's Ars Amatoria I and II failed to find a publisher in South Africa or the UK; Prinsloo to Murgatroyd, 1 April 1980; Murgatroyd to C, 24 April 1980. It later appeared as Ovid with Love: Selections from Ars Amatoria I \& II (Chicago 1982); reviewed by S Bruwer, Akroterion 28.1/2 (1983) 53-55.

58 Prinsloo to C, 21 June 1979; C to Prinsloo, 6 August 1979; Prinsloo to C, 30 August 1979. See Appendix A.

59 Atkinson to C, 21 May 1980; C to Atkinson, 27 June 1980; Atkinson to C, 17 July 1980.

60 Akroterion 24.4 (1979) 35. 
(see 1.1 above). Early on Prof A G MacKay was considered as the guest speaker for the conference in Durban. Then Dr Atkinson informed the Executive that Francis Cairns (Liverpool) had expressed interest in attending the conference. ${ }^{61}$ The Executive considered it inadvisable to have two guest speakers: CASA could not afford to carry the expenses of an overseas visitor and funding for only one would be forthcoming from the Department of National Education. ${ }^{62}$ There was still the possibility of inviting Prof Hermansen. ${ }^{63}$

After much correspondence and many exchanges of views, a provisional programme, incorporating conference decisions and circulated to members of the Executive for comment and approval, was finalised. ${ }^{64}$ Two innovations were introduced to accommodate all the papers offered: instead of a chairperson for each speaker, one person would chair a whole day's proceedings; and there would be a double session, each with its own chairperson, on the last day. An invitation was sent to all members to attend the conference; attached were summaries of the twenty papers to be delivered. ${ }^{65}$

\subsubsection{FIEC}

Prof Arnheim had to report on the advisability of continued membership of the FIEC and the possibility of affiliation with other, more classically orientated bodies. In the absence of a report, the Executive would recommend continued membership. After a reminder, the report was sent to the Chairperson. ${ }^{66}$ Prof Drijepondt notified the Executive that he would be available to represent CASA at overseas conferences during $1980-81 .{ }^{67}$

\subsection{Regional Branches}

Some clarification was requested and given concerning the reports of regional branches. According to Article 4(b) of the constitution, the annual grant to any

61 S to C, 21 March 1980; Atkinson to C, 21 May 1980.

62 Minutes of meeting, 16 April 1980; C to Atkinson, 27 June 1980; S to C, 23 July 1980.

63 C to S, 27 June 1980.

${ }^{64} \mathrm{~S}$ to Executive, 18 August 1980; C to S, 1 October 1980; S to C, 7 October 1980; C to S, 17 October 1980; S to C, 22 October 1980; Lubbe to S, 24 October 1980; S to Executive, 24 October 1980; S to Lubbe, 3 November 1980; S to De Wet, 12 November 1980; Circular to delegates, 19 November 1980.

65 Circular, 27 October 1980.

66 Minutes of Executive Meeting, 2 January 1980; S to Arnheim, 15 January 1980; Minutes of Executive Meeting, 16 April 1980.

${ }^{67} \mathrm{C}$ to S, 13 October 1979. 
regional branch was only paid if an annual report and financial statement for the previous year had been sent to both the Secretary and Treasurer. In addition, branches had been requested at conferences (e.g. at Bloemfontein in 1975) to submit a report on their activities to the Treasurer and Akroterion, instead of the earlier procedure of tabling reports at conferences. ${ }^{68}$ However, since only two branches had complied, it was decided to revert to the previous practice. ${ }^{69}$ Uncertainty also arose as to the interpretation and intent of the decision by the previous conference concerning the increased grant to Regional Branches. The interpretation of the out-going Treasurer was that the annual grant to Regional Branches was now a minimum of R15 for branches with 30 or fewer members, and then $\mathrm{R} 1$ per member in excess of 30 . Thus: a branch of 60 members would receive $\mathrm{R} 15+\mathrm{R} 30=\mathrm{R} 45$. However, the Western Cape Branch, which had proposed the motion, had intended the increase for all members of a branch. Thus: a branch of 60 members would receive R60. ${ }^{70}$ The matter was clarified: payments in 1979 for 1978 would be based on the constitution then applying, viz. 50c per member with a minimum of R15 with the option to request more; for payments in 1980 for 1979 the new regulation would apply, viz. R1 per member with a minimum of R15 per branch. ${ }^{71}$

\subsubsection{Western Cape Branch}

In 1978-79 Prof Baumbach and Mr R Whiteford visited junior schools to promote interest in Latin. In an effort to cater for the needs of teachers, an evening meeting was arranged in February 1979 at which Drs Bruwer and Van Stekelenburg introduced Tria Saecula which was now being used in Cape Senior Certificate schools instead of Petrie's Latin Reader. In May a workshop with the title "The nuts and bolts of Latin teaching" was held on Latin teaching. A general meeting devoted to slavery in the ancient world was held at Stellenbosch on 5 May 1979. Among the speakers were Dr J E Schiller (Law Faculty, UCT), Mr N Worden and Mr J C Sang. The new committee for 1979-80 consisted of Dr Atkinson (C), Mr B de Kock (VC), Dr K M Coleman (S), Mr Sang (T), Ms S Armstrong (S for schools), Mrs J M Claassen, Prof Conradie, Mr Zietsman, Mrs B Millar, Dr Van Stekelenburg, Miss M Catacousinos, Miss E Cartwright and Mr J van der Riet (AM). ${ }^{72}$

\footnotetext{
68 Cf. Henderson 2007:108 with n. 58.

${ }_{69}$ Murgatroyd to C, 6 February 1979; C to Murgatroyd, 13 February 1979.

70 Basson to T, 18 February 1979; J C Sang to T, 4 April 1979; T to C, 21 May 1979.

71 C to T, 7 June 1979.

72 Report in Akroterion 24.4 (1979) 35-37.
} 
At a Teachers' Meeting on 6 February 1980 Mr K Kirby gave a talk on "Roman administration, central and provincial", which was a topic for the Cape Senior Certificate for 1980. ${ }^{73}$ Prof Smuts and Drs Bruwer and Van Stekelenburg discussed ideas and problems connected with Tria Saecula. At a general meeting in May, attended by a large audience, Mr R Smith gave a talk on "Greek oracles" and Dr B Flemming (of the Marine-Geology Research Unit) spoke on "Underwater archaeology". At a film evening in July "Cycladic Civilization" was the main feature. Six schools participated in another successful quiz which this time filled the evening's programme. The popular and successful Reading Competition was attracting increasing interest from schools which had previously avoided the activity. Also, Ludi Romani, a Latin eisteddfod for Std 6-8 pupils, subsidised by the Italian Consulate, were held..$^{74}$ At the AGM on 23 August 1980 Dr Atkinson announced that he would no longer be available to serve as Chairperson. The editors of Akroterion wrote an appreciation of his contribution to Classics. ${ }^{75}$ On 8 October 1980 a cheese and wine party for Head Teachers of high schools in the Western Cape was held at the University of Cape Town. It was hoped that closer ties between the schools and the Association would arrest the decline of Latin. Dr P Greenhalgh and Mr Whiteford emphasised the value and necessity of learning Latin at school. After a light supper Mr Flemming gave an illustrated talk on "Diving for history". ${ }^{76}$ Additional funds (R80) from the central treasury were approved for the Ludi as well as for the reception for school principals. $^{77}$

\subsubsection{Free State Branch}

A very successful meeting for pupils was organised by the branch on 27 April 1978, at which Messrs Cilliers and L van Ryneveld presented talks on the background topic: "The Roman Empire in the time of Augustus", prescribed for the Free State Senior Certificate for $1979 .{ }^{78}$ A similar Latin Pupils' Day at the University of the Orange Free State was organised in 1979. About 400 pupils, seated in the well appointed Odeion, listened to lectures with slides and took part in a quiz. At the AGM at the end of 1979 teachers were enlightened on the requirements for the matriculation examination in Latin. Film shows on Greek

See Kirby 1980.

Report in Akroterion 25.3 (1980) 31-32.

Editors, Akroterion 25.3 (1980) 32.

Report in Akroterion 26.4 (1981) 39.

77 C to S, 27 June 1980; C to T, 27 June 1980; C to Atkinson, 27 June 1980; Atkinson to C, 17 July 1980; T to C, 18 August 1980.

78 Report in Akroterion 24.3 (1979) 49. 
mythology and drama attracted school pupils and students from other disciplines. A lively debate between pro- and anti-Latinists appeared in the Letters to the Editor section of the local Die Volksblad. ${ }^{79}$

\subsubsection{Transvaal Branch}

Genuine interest and enthusiasm of teachers and committee members were reported. On 24 February 1979 a Subject Conference of the Transvaal Teachers' Association was addressed by Miss J Brodrick on Caesar and Miss B Thompson on aspects of the background topic and examination requirements. The Latin Study Committee of the Transvaal Education Department arranged two highly successful Latin evenings to give guidance to Std 5 pupils and their parents about choosing Latin as an optional subject at high school. The Pretoria meeting was attended by 250 people and the Johannesburg one by 400 . There were displays of books, projects, models and pictures; past and present Latin pupils talked about the value of Latin for them; and short plays were presented by the Afrikaanse Meisieskool, Rivonia Primary School and Hoërskool Verwoerdburg. At the Teachers' Conference on 17 March 1979, attended by 40 teachers, Ms Thompson spoke on "The teaching and testing of reading for comprehension", ${ }^{80}$ which was followed by a workshop. Mr Barnicoat gave a talk on "The birds in some Roman writings", illustrated with books, pictures and live birds. ${ }^{81}$ On 4 May 1979 Prof Henderson presented a workshop on scansion at RAU for teachers and pupils, but the annual Latin Reading Competition scheduled for 9 June had to be cancelled due to insufficient entries.

At the AGM, on 22 September 1979, a talk with slides was presented by Mrs E Rankin (Fine Arts, Wits) on "The Acropolis" and Prof A Burger (Architecture, Pretoria) highlighted aspects of the effects of the eruption of Vesuvius and the excavations at Pompeii. He then conducted a tour around a large scale-model of the House of Menander built by students of the Architecture Department. After lunch delegates were treated to a performance, by drama students, of the Menaechmi, adapted into Afrikaans by Mr Scholtemeijer. The committee for 1980 was elected: Mr De Villiers (C), Dr Mans (VC), Mr Barnicoat (ST), Messrs G Mader, Simpson, C M Jooste, J P L Wolmarans (AM), Mrs F Lonstein and S Nell, Ms Brodrick and Möller (Schools Representatives). Gratitude was expressed to Mrs Shillington, who had

\footnotetext{
79 Report in Akroterion 25.3 (1980) 30.

80 See Thompson 1980.

81 See Barnicoat 1979.
} 
retired in December 1979, for her contribution to the activities of the Transvaal Branch over many years. ${ }^{82}$

During 1980 there were changes to the committee: Mrs B Van Zyl Smit replaced Mr Wolmarans, and Mrs D Eftychis and Dr M Scott were co-opted. Tribute was paid to Prof Petrie and Mrs Shillington. A Teachers' Conference was held on 15 March 1980 at which the following papers were delivered: Prof Kriel, "Romeinse beskouinge oor lewe ná die dood"; Mr C Harrop-Allin, "The Roman forum - physical aspect"; Mr D Cook, "Poster painting and mythology - a demonstration"; and Dr P Boltman, "Menander — the story of a model". During April a five-day orientation course for teachers was held at the Johannesburg College of Education. Various aspects of the syllabus were dealt with, including pronunciation, oral reading, scansion, reading for comprehension, and the Ecce Romani series. The Reading Competition, planned for 14 June, attracted many entries, but due to problems in finding a venue had once more to be cancelled. The AGM was held on 27 September 1980 and the following new committee members were elected: $\mathrm{Mr}$ Mader (ST), Mr Van der Walt and Dr Scott (AM), Mrs G Glen and $\mathrm{Mr}$ Barnicoat (Representatives for schools). ${ }^{83}$

\subsubsection{Natal Branch}

During the period 1979-80 several seminars relating to the Matriculation Latin syllabus were presented by the Durban and Pietermaritzburg Departments of Classics. In addition, talks and slide-shows were given at various schools: Ms C Chapman, "Catullus and Lesbia"; Mrs P Bruce, "Oracles"; Ms L du Toit, "Animals in the ancient world"; $\mathrm{Mr} \mathrm{D}$ Pike, "Greek mythology"; Prof M M Henderson, "The Etruscans"; Dr Murgatroyd, "Caligula", "Elagabalus", "Catullus, Poem 4"; Dr R Whittaker, "The fall of Troy"; Mrs A Gosling, "Pompeii"; Dr Chapman, "Roman attitudes towards the Christians in the 1st and 2nd centuries A.D."; Prof De Wet, "Pompeii and Herculaneum"; Mrs S MacNab, "The Parthenon". At the AGM Dr Murgatroyd read a paper on "Ovid's narrative technique" ${ }^{84}$

\footnotetext{
82 Report in Akroterion 25.1 (1980) 35-37.

83 Report in Akroterion 26.1 \& 2:64-66.

${ }^{84}$ Report in Akroterion 25.3 (1980) 29.
} 


\section{Fourteenth CASA conference, $19-23$ January 1981, Durban}

\subsection{Conference proceedings}

The First Business Meeting on 20 January 1981, attended by 39 delegates, was welcomed by the Chairperson, Prof Henderson. A special word of welcome was extended to Mrs N Tzafalia who was representing the Ambassador of Greece. The delegates stood in silent tribute to colleagues who had passed away since the previous conference: Prof Petrie, ${ }^{85}$ Prof Raven (Visiting Professor at Witwatersrand University in 1971), Mrs Shillington ${ }^{86}$ and Prof Van Rensburg. ${ }^{87}$ Dr Viljoen, an Honorary President of CASA and former Rector of RAU, was congratulated on his appointment as Minister of Education.

The first matter arising out of the minutes of the previous conference concerned the Latinless LL.B. Dr Bruwer tabled the report of the actions undertaken by the Executive Committee as outlined above (the letter to the Secretary of Justice and the memorandum to the Committee of University Principals). The report also included the response of the CUP, which endorsed four principles formulated by Dr Bruwer: "(a) In the interest of uniform academic standards, attention should be given to the standardisation of the Latin component of the LL.B. course. (b) A one-year course in Latin at university not preceded by Matriculation Latin could not be regarded as academically meaningful. (c) It was desirable that Latin (that is, a one-year university course in Latin preceded either by Matriculation Latin or a one-year preliminary university course in Latin) should be a prerequisite for, rather than a requirement for obtaining, the LL.B. degree. (d) Urgent attention should be given to the anomalous situation existing at a University like that of Zululand as against others like those of the North and Durban-Westville - all falling under the Committee of University Principals." The CUP also referred the matter to the Committee of University Rectors, which controlled the "Non-White" universities. This body also expressed its opposition to a Latinless LL.B., yet endorsed an LL.B. with only preliminary Latin. The report was accepted with appreciation, and the new Executive was authorised to pursue this matter as it deemed fit, with the power to co-op three additional members in order to liaise with Latin departments of universities that awarded law degrees with only a single year of Latin. Dr Bruwer was requested to make representations to the Hoexter Commission on behalf of the Association.

\footnotetext{
85 See Clarence 1980; Smuts 1980a.

86 See Akroterion 25.2 (1980) 30-31.

87 See Smuts 1980b.
} 
Also arising from the previous minutes was a request to the Regional Branches to submit their annual reports to the Secretary who would forward them to Akroterion. Prof Gain had notified the Secretary that the Eastern Cape Branch no longer existed. It was, however, pointed out that a Regional Branch could not unilaterally decide not to function; only the Executive could abolish a Regional Branch. Several suggestions were offered from the floor: that the annual symposium for Teachers held at the Monument by Rhodes University, as well as slide-shows presented by the lecturers should take place under the auspices of the local branch of the Classical Association; that activities of the Association (slideshows and co-ordination with the Teachers' Centre and inspector of schools) be revived in Port Elizabeth. The two universities were requested to submit a proposal to the Executive that they be allowed to operate as separate units, or sub-branches.

The Chairperson reported that Prof Arnheim had recommended CASA's continued affiliation with the FIEC. After Prof Saddington had emphasised the value of membership of the body, it was decided to appoint a permanent representative. Prof Hendrickx was unanimously elected.

The meeting ratified the agreement with the Library of Unisa concerning the holding and management of the exchange periodicals, which had been signed in 1979 by the Chairperson on behalf of the Association. According to this arrangement, the periodicals would become the property of Unisa in return for the cost and labour of binding, storing and cataloguing; members of CASA would receive free photocopies of articles from these periodicals via the Interlibrary service; where this was not possible, requests could be channelled through a colleague in the Classics Department at Unisa.

The final matter arising from the minutes was a report by Prof Kriel on the negotations in connection with the Canadian Academic Centre in Rome. With the assistance of Mr Ballard-Tremeer of the South African Embassy, he had consulted with British, Canadian and Italian academics in Rome during December 1979, and subsequently with the President of the HSRC and the Department of Foreign Affairs in Pretoria (May 1980) and His Excellency, Mr Milis, South African Ambassador in Rome (October 1980). The latter had offered the assistance of the Embassy "for a trial period of two to three months in ... December 1981-January 1982 involving 6-8 people from a variety of disciplines" to evaluate the need for and possibility of a base for South African researchers in Rome. Prof Kriel was unanimously chosen as a one-man committee entrusted with the task of liaising with other colleagues in the humanities to take part in the trial period.

The agenda then focused on the various reports. The Chairperson reported a membership of 340, of whom 84 had joined in 1980, mostly as a result of the exemplary effort of the Western Cape Branch. Regional Branches were granted extra funds for special projects and this was to be encouraged in future. All efforts 
to obtain a guest speaker from abroad had failed; yet this was of the utmost importance for the Association. During its term of office, the Executive had managed to hold two meetings which nearly all the members had been able to attend and this practice was recommended to future committees. Prof Naudé, Dr Atkinson and $\mathrm{Mr}$ Cilliers were chosen to form a subcommittee to co-ordinate arrangements for visits by foreign scholars. Universities would then share the costs of the visit.

The financial report was tabled by Dr Mans. The savings account reflected a credit balance of R 1 279,53, while there was R2 553 on fixed deposit. Payments had been made to Acta Classica (R2 000), Akroterion (R550) and FIEC for 1979 and $1980(\mathrm{R} 77,16)$. A recommendation that the fees for student members registering for three years in advance be raised to R5 was approved.

In his report on Acta Classica, Prof Naudé explained that the early appearance of Volumes XXII (1979) and XXIII (1980) in December - in accordance with the aim to ensure publication in the year of a volume's date had caused a gap between the arrival of the publisher's account and the payment of funds into the editorial budget. This had necessitated a private loan of R2 090 to the editorial account. The Editorial Committee had therefore applied to the HSRC for a grant of R3 500 to form a reserve fund. The result of the request was still awaited. However, the Editorial Committee had managed to pursuade the HSRC to increase the annual subsidy from R1 500 to R2 000 as from 1980. The costs for recent volumes were gradually rising: Vol. XXI (1978), 169 pages, R3 082, XXII (1979), 177 pages, R3 436, and XXIII (1980), 150 pages, R3 719. In order to reduce costs, footnotes would be published at the end of each article instead of at the bottom of the page. Drastic measures were also required to reduce the cost of authors' corrections at the proof-reading stage. In future a set of guidelines would be printed at the end of each volume. Finally, members who required articles from the exchange periodicals but whose universities charged a fee for Interlibrary Loans, were to contact the Editorial Committee. A copy of the agreement between the Association and the Library of Unisa was appended. The meeting suggested that back numbers of Acta Classica should be offered at a reduced price to universities abroad and that an administrative assistant be appointed to alleviate the committee's work load. The price per volume of Acta Classica was set at R12.

Prof Smuts tabled the report on Akroterion. Costs had increased alarmingly from 5,4 cents per page in 1979 to 7,2 cents in 1980; a volume now cost close to R2. The University of Stellenbosch had increased its subsidy from R330 to R400 as from 1981. The meeting decided to increase the annual grant of the Association to R400 per annum. It was suggested that Regional Branches should ask their 
Departments of Education to subscribe to Akroterion on behalf of the schools as had been done by the Transvaal Education Department.

Dr Bruwer, convener of the Standing Committee for Latin at School, reported that she and Prof Smuts had conferred with the other members of the ad hoc Advisory Committee set up by the HSRC for their enquiry into the teaching of Latin at secondary schools (see above, 1.2.2) in Stellenbosch in October 1979. The first official meeting took place in Pretoria on 15 April 1980. Five bilingual questionnaires of more than 275 typed pages were being processed by computer for circulation and the results would be communicated first to CASA as the initiator of the project.

Prof Henderson, convener of the Subcommittee for Publications, reported that publishers such as Butterworths, Perskor and MacMillan had been contacted, but that, since the subcommittee, representing all the universities, could do nothing more than liaise, little more could be achieved. The subcommittee should be dissolved, but the following pursued: co-authorship of books which could then be prescribed at more than one university; and the interpersonal exchange of developed courses or relevant projects. Prof Henderson was requested to continue as informal facilitator between publishers and authors.

Prof Kriel gave notice of a motion for the Second Business Meeting regarding the procedure and criteria for the dedication of individual volumes of Acta Classica to deserving classicists.

At the end of the meeting, Dr Bruwer proposed the appointment of a committee, which was to report back at the Second Business Meeting, on the feasability of a two-day, biennial conference on the teaching of the classical languages and culture, to be held inbetween the normal conferences. As motivation she mentioned the importance of didactics in keeping Classics alive and up to date, relieving the programme of normal conferences, offering another opportunity of meeting with colleagues, attracting younger members of departments, more financial support from universities, and greater relevance for school teachers. The motion was adopted and the following appointed: Proff Baumbach (Cape Town) and De Wet (Natal), Drs Mans (Pretoria) and Matier (Rhodes), Ms Lewis (Port Elizabeth), Messrs J Hilton (Fort Hare), Tronson (Unisa), Van Ryneveld (Orange Free State) and Wolmarans (Rand Afrikaans).

Twenty-seven delegates attended the Second Business Meeting on 23 January 1981. Prof Gonin was congratulated in absentia on receiving an honorary doctorate from the University of Pretoria in 1980. The committee on the proposed didactic colloquium had co-opted Dr Atkinson (Cape Town), Ms L J Raath (Zululand) and Mrs I Torr (Unisa) and met on 12 January. The committee unanimously supported the idea of such a colloquium and suggested that the first one should be on the teaching of beginners' courses in Greek and Latin. 
Further recommendations were that future programmes should involve school teachers; that colloquia should alternate between southern and northern centres, starting in the south; that the first colloquium should be held over two days in March 1982; that a committee consisting of Dr Bruwer, Dr Atkinson and Prof Baumbach should organise the first colloquium; and that the additional member of the Executive Committee should oversee the colloquium. The principle of a colloquium and the recommendations were accepted. ${ }^{88}$

The following motions were passed:

1. Specific volumes of Acta Classica would be dedicated to deserving persons after consideration by the Editorial Committee of Acta Classica and ratification by the Executive Committee. The following guidelines were laid down: (1) the dedication would occur on or after retirement with the knowledge and approval of the honorandus; posthumous dedications would not be excluded; (2) the following considerations would apply: (i) an active role in the activities of the Association; (ii) long service to the Classics, for example in the teaching and development of young classicists; (ii) academic achievements in research and publications; (3) an application could come from the Executive, Editorial Committee or any member of the Association.

2. In the light of the increased grant to Acta Classica membership fees of Full Members were to be raised from R10 per annum to R15 per annum, and of Associate Members from R4 to R5.

3. A conference fee to cover inter alia transport to and from the airport, refreshments and secretarial assistance was henceforth to be assessed by the host university and paid by delegates during the conference. Attendance at sessions would be free to members of the public and students.

4. Acta Classica would be expanded to include volumes of monographs which would have to be funded by the author.

A proposal that the conference be held during the June / July vacation was rejected.

The following were appointed to the Editorial Committee: Prof Gonin (Editor), Prof. Naudé (Treasurer), Prof Vogel-Weidemann (Additional Member)

88 Minutes of Executive Meeting, 19 January 1981; Minutes of First Business Meeting, 20 January 1981; cf. also Report, Akroterion 26.1 \& 2:60-63. The Colloquium was later planned for 21-23 April 1982; report in Akroterion 26.4 (1981) 34-36. 
and $\mathrm{Mr}$ Hasse (Secretary). The following representatives of universities were nominated to the Board: Prof Arnheim (Wits), Prof Baumbach (Cape Town), Prof Benade (North), Prof Botha (Port Elizabeth), Dr G H Chapman (Natal, Durban), Prof Cipolla (Durban-Westville), Prof Conradie (Stellenbosch), Prof De Kock (Rand Afrikaans), Prof Drijepondt (Orange Free State), Prof Els (Fort Hare), Prof Gain (Rhodes), Prof M M Henderson (Natal, Pietermaritzburg), Prof Louw (Pretoria), Prof Saddington (Zimbabwe), Dr Simpson (Potchefstroom), Prof Snijman (Western Cape), Prof Van der Walt (Zululand) and Prof Van Rooy (Unisa). The Standing Committee for the Position of Latin at School remained unchanged, but that for Classical Culture replaced all previous subcommitees concerned with the desirability of Classical Culture at school. The subcommittee consisted of Prof De Wet (Natal), Prof Smuts (Cape Province), Prof Henderson (Transvaal) and Mr Van Ryneveld (Orange Free State), with powers to co-opt. ${ }^{89}$

At a closed session, Prof Smuts was unanimously made an Honorary President of CASA..$^{90}$ The new Executive Committee for the period 1981-1983 would be Prof Kriel (C), Prof De Wet (VC), Dr Bruwer (S), Dr Atkinson (T) and Prof Henderson (AM). Votes of thanks were expressed to the Principal and University of Natal, Durban for the warm hospitality and excellent facilities, to the Department of Classics for arrangements in connection with the accommodation, the excursions and practical matters, and to the outgoing Chairperson, Prof Henderson, and the Secretary, Dr Bruwer, for the new initiatives undertaken during their term of office. Members were reminded of the principle of bilingualism (English and Afrikaans): papers in one official language were to be provided with a summary in the other language; reports could be written in one language and presented orally in the other, or the languages alternated at each conference. The new Executive was given the authority to expand the use of double or concurrent sessions. ${ }^{91}$

Twenty-one papers were read during the conference. Of particular relevance in the context of the threatened position of Latin was the paper by Prof De Wet on the advisability of introducing Classical Civlisation courses at school level..$^{92}$ There were two excursions: to the Tongaat Sugar Estate and the beach (Wednesday afternoon) and to the Natal Sharks Board and Umhlanga Rocks (Thursday afternoon).

\footnotetext{
89 Cf. also Report, Akroterion 26.1 \& 2:63.

90 Proposed by Atkinson to C, 7 January 1980.

91 Minutes of Second Business Meeting, 23 January 1981.

92 See De Wet 1981, with a response by Murgatroyd 1982.
} 


\section{BIBLIOGRAPHY}

Atkinson, J E 1978. Western Cape teachers in commentaries project. Akroterion 23.1 \& 2:46-47.

Barnicoat, F 1979. A few examples of the study and keeping of birds in the Roman world. Akroterion 24.2:18-23.

Clarence, D 1980. Tribute to Alexander Petrie at the memorial service held in Pietermaritzburg on Tuesday, 11 December 1979. Akroterion 25.1:4-6.

De Wet, B X 1981. Is there a place for Classical Civilisation at school? Akroterion $26.1 \& 2: 2-15$.

Drijepondt, H L F 1982. C A van Rooy, Antieke Griekse geskiedenis (van die Steentydperk tot die eeu van Perikles). Butterworth \& Co., Durban. Akroterion 27.1:31-34.

Henderson, W J 2004. The Classical Association of South Africa: April 1956 January 1961. Akroterion 49:89-109.

Henderson, W J 2005. The Classical Association of South Africa: February 1961 July 1966. Akroterion 50:109-123.

Henderson, W J 2006. The Classical Association of South Africa: July 1966 January 1971. Akroterion 51:135-156.

Henderson, W J 2007. The Classical Association of South Africa: January 1971 January 1975. Akroterion 52:99-114.

Henderson, W J 2008. The Classical Association of South Africa: January 1975 January 1979. Akroterion 52:99-114.

Hendrickx, B 1981. C A van Rooy, Antieke Griekse geskiedenis (van die Steentydperk tot die eeu van Perikles.) Butterworth, Durban-Pretoria 1980. AClass 24:171-174.

Kirby, K 1980. Roman administration, central and provincial. Akroterion 25.1:7-14.

Kriel, D M 2009. In memoriam G van N Viljoen (11.09.1926-29.03.2009). AClass 52:vii-x.

Martin, P 2009. Gerrit Viljoen: Serious player in SA's transition. Sunday Times 5 April 2009.

Murgatroyd, P 1982. Classical Civilisation at school: Some cautions. Akroterion 27.1:22-25.

Petrie, A 1980. On old age. Akroterion 25.1:1-3 (transcribed and edited from a tape recording by $\mathrm{H} \mathrm{L}$ Gonin).

Scott, S 1980. Die waarde van Latyn vir die regstudie. Akroterion 25.4:26-30.

Smuts, F 1980a. Alexander Petrie, 1881-1979. Akroterion 25.1:1. 
Smuts, F 1980b. In memoriam: J P J van Rensburg. 23.8.1911-21.11.1980. Akroterion 25.4:1, 32.

Smuts, F 1981. Henri Louis Gonin - 'n waardering. AClass 24:x-xiii.

Trengove, J 1980. Latyn en die opleiding van die regsgeleerde. Akroterion 25.4:23-25.

Thompson, B 1980. The reading of Latin for comprehension. Akroterion 24.2:31-37.

Van Warmelo, P 1981. Henri Gonin as regsgeleerde. AClass 24:xiv.

Viljoen, G van N 1980. Die waarde van die studie van die Klassieke. Akroterion 25.2:2-7.

\section{Appendix A}

School and University Texts published 1979-1981

Atkinson, J E 1980. A commentary on Q. Curtius Rufus' Historiae Alexandri Magni Books 3 \& 4. Amsterdam: Hakkert.

Blanckenberg, N A 1980. Vergilius. Van wapens en 'n man. Durbanville: Uitgewery Boschendal.

Drijepondt, H L F 1979. Die antike Theorie der varietas als Stil- und Strukturmittel. Spudasmata 37. Hildesheim.

Hasse, P 1981. Publications received in exchange for Acta Classica (15th May 1980-15th May 1981). AClass 24:179-189.

Hiemstra V G \& Gonin, H L 1981. Drietalige regswoordeboek / Trilingual legal dictionary. Cape Town, Wetton \& Johannesburg: Juta \& Co. Ltd. 2nd edition 1986.

Kruger, G v N 1981. Die skrywers van die Nuwe Testament. Stellenbosch: Universiteitsuitgewers.

Louw, J P 1979. A semantic discourse analysis of Romans. 2 vols. Pretoria: University Press.

Lubbe, W J G 1979. Latyn vir Regte / Latin for Law, I \& II. Pretoria: University Press.

Lubbe, W J G 1980. Latyn vir Regte / Latin for Law, III. Pretoria: University Press. Reviewed by J Hilton, Akroterion 27.3.3 (1982) 152-156.

Murgatroyd, P 1980. Tibullus I. A commentary on the first book of the Elegies of Albius Tibullus. Pietermaritzburg: University of Natal Press. Reviewed by G J Mader, AClass 24 (1981) 175-177; response by Murgatroyd, AClass 25 (1982) 145-147.

Simpson, H W 1980. Institusie van die Christelike godsdiens (1536) deur Joh. Calvyn. Potchefsroom: Universiteitsuitgewery. 
Smuts, F, Bruwer, S M \& Van Stekelenburg, A V (edd.). 1981. Lexis Latina. Stellenbosch: University Press. 3rd edition 1985 [contributors J M Claassen, S F de Vries, F R Pauw, S Thom and J C Zietsman]. Dedicated to the memory of Suretha Bruwer, initiator of the project.

Smuts, F, Bruwer, S M \& Van Stekelenburg, A V (edd.). 1978?-1983. Tria Saecula. Stellenbosch: University Press:

- [no date] 1978-1979? Vergilius. Ovidius. Commentary / Kommentaar and Teacher's handbook / Onderwysershandboek [contributors W J Henderson, E van Zyl Smit, J M Claassen].

- [no date] 1978-1979? Catullus. Cicero. Commentary / Kommentaar and Teacher's handbook / Onderwysershandboek [contributors W J Henderson, E van Zyl Smit, J M Claassen].

- [no date] 1978-1979? Plinius. Commentary / Kommentaar and Teacher's handbook / Onderwysershandboek [contributors W J Henderson, E van Zyl Smit, J M Claassen].

- 1980. Texts / Tekste [compiled by F Smuts, S M Bruwer and A V van Stekelenburg].

- 1980. Plinius. Commentary / Kommentaar and Teacher's handbook / Onderwysershandboek [compiled by F Smuts].

- 1980. Martialis. Commentary / Kommentaar and Teacher's handbook/ Onderwysershandboek [compiled by A V van Stekelenburg].

- 1982. Introductions / Inleidings [compiled by S M Bruwer and A V van Stekelenburg].

- 1982. Cicero. Commentary / Kommentaar and Teacher's handbook / Onderwysershandboek [compiled by A V van Stekelenburg with cooperation of J M Claassen].

- 1982. Ovidius. Commentary / Kommentaar and Teacher's handbook / Onderwysershandboek [compiled by S M Bruwer with co-operation of A V van Stekelenburg].

- 1983. Vergilius. Commentary / Kommentaar and Teacher's handbook / Onderwysershandboek [compiled by W J Henderson, S M Bruwer and A V van Stekelenburg].

Van Rensburg, J J J 1980. Inleiding tot die semantiek van Nuwe Testamentiese Grieks. Potchefstroom: University Press.

Van Rensburg, J J J 1980. Paidagogos. Potchefstroom: University Press.

Van Rensburg, J P J 1979. Sophocles, Oidipus by Kolonos. Kaapstad: Human \& Rousseau. 
Van Rooy, C A 1980. Antieke Griekse geskiedenis (van die Steentydperk tot die eeu van Perikles). Durban \& Pretoria: Butterworths. Reviewed by H L F Drijepondt, Akroterion 27.1 (1980) 31-34; B Hendrickx, AClass 24 (1981) 171-174.

\section{Appendix B Cape Schools project}

Cartwright, E, Robins, M, Wilcox, T, Wilson, M \& Atkinson, J 1979. Cicero: In Verrem IV 94-98 (= Petrie pp. 61-3). Akroterion 24.1:3-7.

Claassen, J M 1981. The lives and times of the Flavian emperors. Akroterion $26.1 \& 2: 30-45$.

De Vries, S F, Thom, S, \& Van Stekelenburg, A V 1979. Suicide of Dido. A commentary on Petrie's Virgil 276-305 ( = Aeneid IV, 642-671). Akroterion 24.2:14-17.

Van Zyl, D J, Rix, S, Pauw, F, Zietsman, J C, \& Van Stekelenburg, A V 1979. Trojan adventures in Sicily. A commentary on Petrie's Virgil 227-246 and 247-275 (= Aeneid III 568-587 and 655-681). Akroterion 24.1:8-14. 